\title{
The origin of the Popiel peridotite (Western Sudetes, SW Poland): metamorphism of the island arc tholeiitic cumulate
}

\author{
Anna KUKUŁA ${ }^{1, *}$, Jacek PUZIEWICZ ${ }^{1}$ and Theodoros NTAFLOS ${ }^{2}$ \\ 1 University of Wrocław, Institute of Geological Sciences, pl. M. Borna 9, 50-204 Wrocław, Poland \\ 2 University of Wien, Department of Lithospheric Research, Althanstrasse 14, 1090 Wien, Austria
}

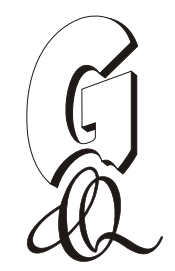

Kukuła, A., Puziewicz, J., Ntaflos, T., 2015. The origin of the Popiel peridotite (Western Sudetes, SW Poland): metamorphism of the island arc tholeiitic cumulate. Geological Quarterly, 59 (2): 239-247, doi: 10.7306/gq.1214

\begin{abstract}
A small $(280 \times 140 \mathrm{~m})$ outcrop of peridotite occurs on Popiel Hill (Sudetes, SW Poland) within the low-grade metabasic rocks of the Rudawy Janowickie Complex, which form the eastern and northeastern cover of the Variscan Karkonosze granite. The peridotite is situated on the Intra-Sudetic Fault, one of the major Variscan dislocations in the region. The rock consists of strongly tectonised olivine $\left(\mathrm{Fo}_{84-88}\right)$ and orthopyroxene (Mg\# 0.84-0.88) aggregates, overgrown by tremolitemagnesiohornblende, locally forming large crystals, embedded in serpentine. Spinel and magnetite are subordinate; ilmenite, Fe-sulfide, and apatite are accessories. The bulk-rock chemical composition suggests a lherzolitic composition and the occurrence of primary clinopyroxene, now completely replaced by tremolite and magnesiohornblende. Rare Earth Element patterns are flat, slightly enriched relatively to primitive mantle, as is typical of island arc tholeiites. Olivine, orthopyroxene, and spinel were the first to crystallize, and they represent relics of a primary igneous assemblage. They were followed by tremolite and serpentine, formed during uplift and related metamorphism. The last mineral to crystallise was magnesiohornblende, which originated due to contact metamorphism by the Karkonosze granite magma. The Popiel peridotite probably represents a small slice of Iherzolitic cumulate, which originated in a tholeiitic magma chamber at the roots of a supra-subduction volcanic arc.
\end{abstract}

Key words: peridotite, cumulate, supra-subduction, Intra-Sudetic Fault, Bohemian Massif.

\section{INTRODUCTION}

The slightly metamorphosed peridotite, occurring on Popiel Hill in the Western Sudetes in SW Poland (Fig. 1), is one of the classic problems of the geology of the region. The very fine-grained peridotite has been a challenge for microscopic studies, which failed to explain the sequence of mineral crystallisation and the origin of the rock, the primary igneous minerals of which are overprinted by metamorphic phases. Consequently, the first proposal regarding the origin of the Popiel peridotite was based on a geochemical study of the surrounding metavolcanic rocks - Narębski $(1990,1993)$ proposed that the Popiel Hill peridotite is of "Alaskan" (i.e. volcanic-arc) type and originated in a supra-subduction tectonic setting, since that is the nature of the surrounding metabasites.

In this study we present detailed petrographic, mineral chemical and geochemical data for the Popiel peridotite. Our observations are based on an electron-microprobe study, which enabled an improved and more detailed rock characterization than petrographic microscope study. For the first time,

* Corresponding author, e-mail: anna.kukula@ing.uni.wroc.pl Received: June 30, 2014; accepted: September 30, 2014; first published online: January 22, 2015 we discuss the sequence of $\mathrm{m}$ etamorphic events recorded in the rock. Our data show that the peridotite is a supra-subduction igneous cumulate, supporting the origin proposed by Narębski $(1990,1993)$.

\section{GEOLOGICAL SETTING AND PREVIOUS WORK}

The serpentinised peridotite of Popiel Hill (Western Sudetes, SW Poland) forms a small outcrop (ca. $280 \times 140 \mathrm{~m}$ ). It is located north-east of the village of Janowice Wielkie (Fig. 1), immediately south of the Intra-Sudetic Fault, one of the major Variscan geological borders in the north-east part of the Bohemian Massif, in Central Europe (Aleksandrowski et al., 1997).

The peridotite is surrounded by low-grade metabasic rocks ("striped metabasites"), belonging to the Kowary Unit of the Rudawy Janowickie Complex (Aleksandrowski et al., 1997), surrounding the Variscan Karkonosze granite to the east and north-east. Popiel Hill is situated within ca. $100 \mathrm{~m}$ of the granite outcrop (Fig. 1). The Rudawy Janowickie Complex consists of lower Paleozoic volcanic (typically N-MORB-type) and sedimentary rocks (e.g., Kryza et al., 1995). The scarce data on the "striped metabasites" surrounding the Popiel peridotite suggest within-plate tholeiite and alkali basalt affinities (Winchester et al., 1995).

The peculiar rock has long attracted Earth scientists. It was first mentioned by Websky (1853), who described it as a 


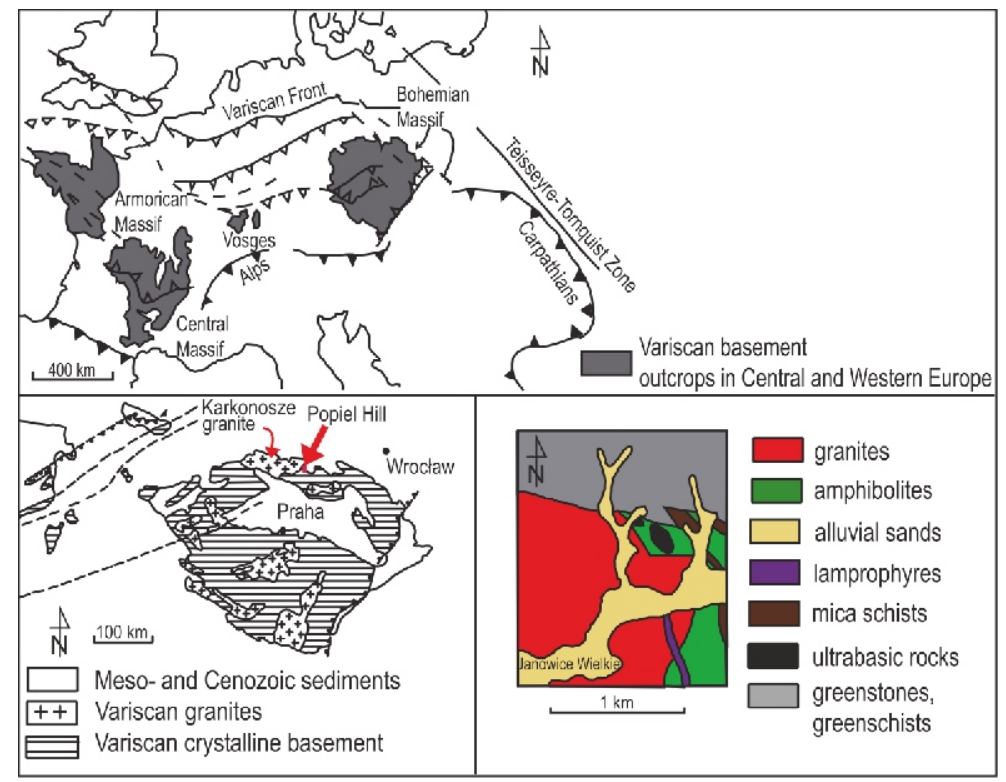

Fig. 1. Location of Popiel Hill, relative to the European Variscan basement and Bohemian Massif and its detailed geological map (after Aleksandrowski et al., 1997)

"...black serpentine-like groundmass full of crystals of <uralite>...". Berg (1912) described partly serpentinised olivine, magnetite, spinel, and large crystals of "uralite", with remnants of augite as the minerals forming the rock (this description was repeated in Berg, 1938). The next petrographic description of the Popiel Hill peridotite was given by Teisseyre (1966), who named the rock hornblende peridotite. According to Teisseyre (1966), the peridotite consists of olivine, primary hornblende, serpentine, iron oxides, and picotite, its origin is magmatic and the Intra-Sudetic Fault played an important role in bringing the rock to its present level of exposure.

Narębski $(1990,1993)$ suggested that the Popiel Hill peridotite is an "Alaskan type intrusion", occurring within a volcanic series of supra-subduction geochemical characteristics. This view was followed by Gunia et al. (1998), who presented trace element data for the peridotite and suggested that the rock is possibly a subduction-related cumulate, resulting from the fractional crystallisation of an ultrabasic melt.

\section{ANALYTICAL METHODS AND TERMINOLOGY}

The data presented in this paper are based on 24 samples. The bulk rock composition of the peridotites (23 samples) was analysed in the ACME analytical laboratory (Vancouver, Canada) by ICP (major elements, the $4 \mathrm{~A} \mathrm{ACME} \mathrm{procedure)} \mathrm{and}$ ICP-MS (trace elements, 4B ACME procedure). The detection limits were $0.01 \mathrm{wt} \%$ oxide for major elements and typically $0.1 \mathrm{ppm}$ for trace elements (details of the analytical procedure and detection limits for each element are available from the authors upon request). The chemical composition of the minerals was analysed in 11 representative thick, polished sections by the Cameca SX 100 electron microprobe at the Department of Lithospheric Research, in University of Vienna under standard conditions (acceleration voltage $15 \mathrm{KV}$, sample current $15 \mathrm{nA}$, counting times 10 or $20 \mathrm{sec}$ ), using natural and synthetic minerals as standards and the PAP correction procedure.

The pyroxene classification of Morimoto (1989) and the amphibole one of Leake et al. (1997) are used in the following.
Spinel compositions were calculated for three cations and $\mathrm{Fe}^{3+}$ was calculated by charge balance. The mg-number (Mg\#) denotes the atomic ratio of $\mathrm{Mg} /\left(\mathrm{Mg}+\mathrm{Fe}^{2+}\right)$ and the cr-number $(\mathrm{Cr} \#)$ represents the atomic ratio of $\mathrm{Cr} /(\mathrm{Cr}+\mathrm{Al})$ in calculated formula units. "Fo" represents forsterite in olivine (calculated as atomic $(\mathrm{Mg} /(\mathrm{Mg}+\mathrm{Fe}+\mathrm{Mn}))^{*} 100 \%$ in formula units). Mineral abbreviations are: Ol (olivine), Opx (orthopyroxene), Mhb (magnesiohornblende), $\operatorname{Tr}$ (tremolite), Spl (spinel), Mag (magnetite), and IIm (ilmenite) according to Kretz (1983) and Whitney and Evans (2010).

\section{PETROGRAPHY AND MINERAL CHEMISTRY}

The long-abandoned quarry in the Popiel Hill is semi-circular in shape. Currently the total length of its wall is 135 metres and its maximum height is 5 metres. The peridotite is dark green to black, fine-grained, locally with millimetre-scale serpentine veins. All the samples studied (19 from the quarry's north and east walls, 2 west of the quarry, 2 north of the quarry, and 1 south-east from the quarry) are texturally similar. The samples from outside of the quarry were collected from loose blocks.

The rock is fine-grained and consists of strongly crushed, fractured, and fragmented grains of olivine, orthopyroxene, and subordinate amphibole or their aggregates, embedded in a serpentine groundmass, or sparsely in chlorite (Fig. 2). Amphibole occurs also in places as a few millimetre-sized skeletal grains (Fig. 2A). Accessories are aluminous spinel, magnetite, rare ilmenite, apatite, and iron sulfides.

The relic primary minerals preserved in the peridotite are olivine and orthopyroxene (Fig. 3A). They are overgrown by amphibole, which consists of tremolite surrounded by magnesiohornblende rims (Fig. 3B). Locally, a few millimetre-sized crystals, consisting of acicular subgrains of tremolite and hornblende, occur (Fig. $3 \mathrm{C}$ ). The amphibole is overgrown by orthopyroxene II, which texturally is contemporaneous with magnesiohornblende (Fig. 3D). The aluminous spinel is commonly rimmed by magnetite (Figs. $3 \mathrm{~A}$ and $4 \mathrm{~A}$ ). 

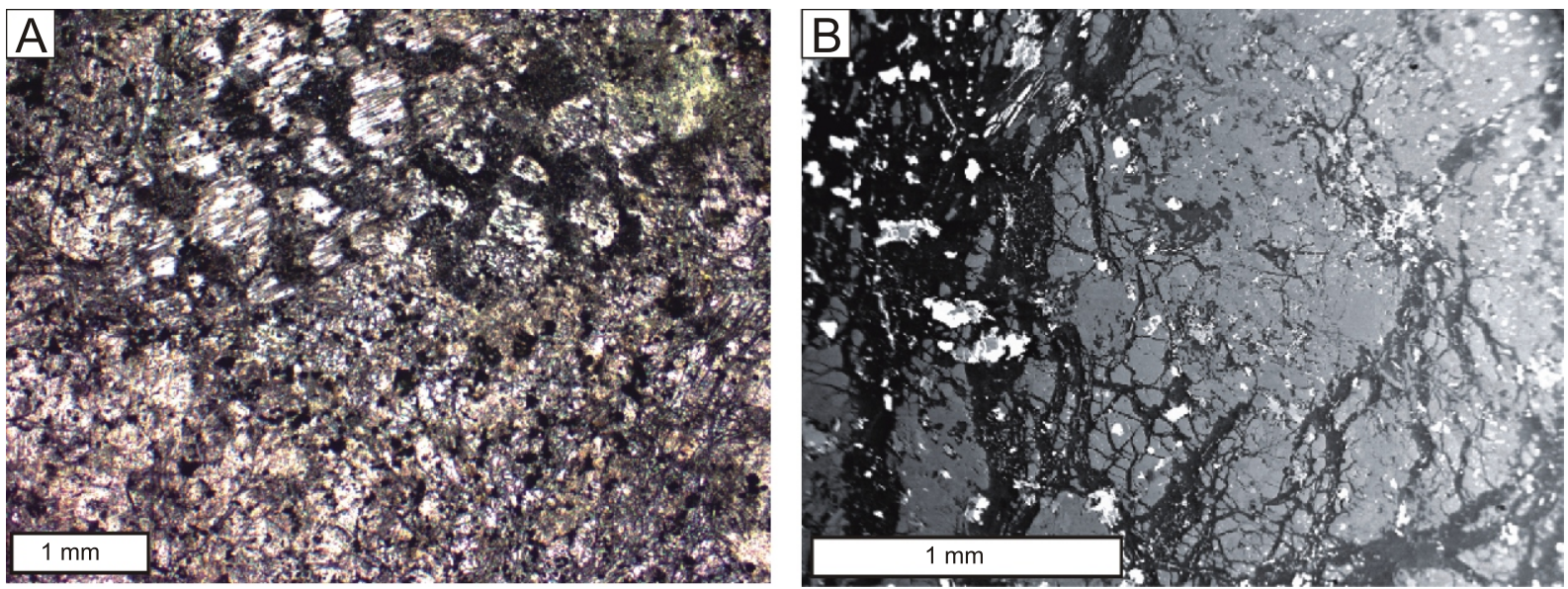

Fig. 2. Texture of the Popiel Hill peridotite

A - skeletal crystal of amphibole ("uralite") embedded in a partly serpentinised olivine-orthopyroxene groundmass, sample 2701, optical image, plane polarized light; B - olivine-orthopyroxene aggregate (grey) embedded in a serpentinite groundmass (black), magnetite grains are white, sample 2703, BSE image
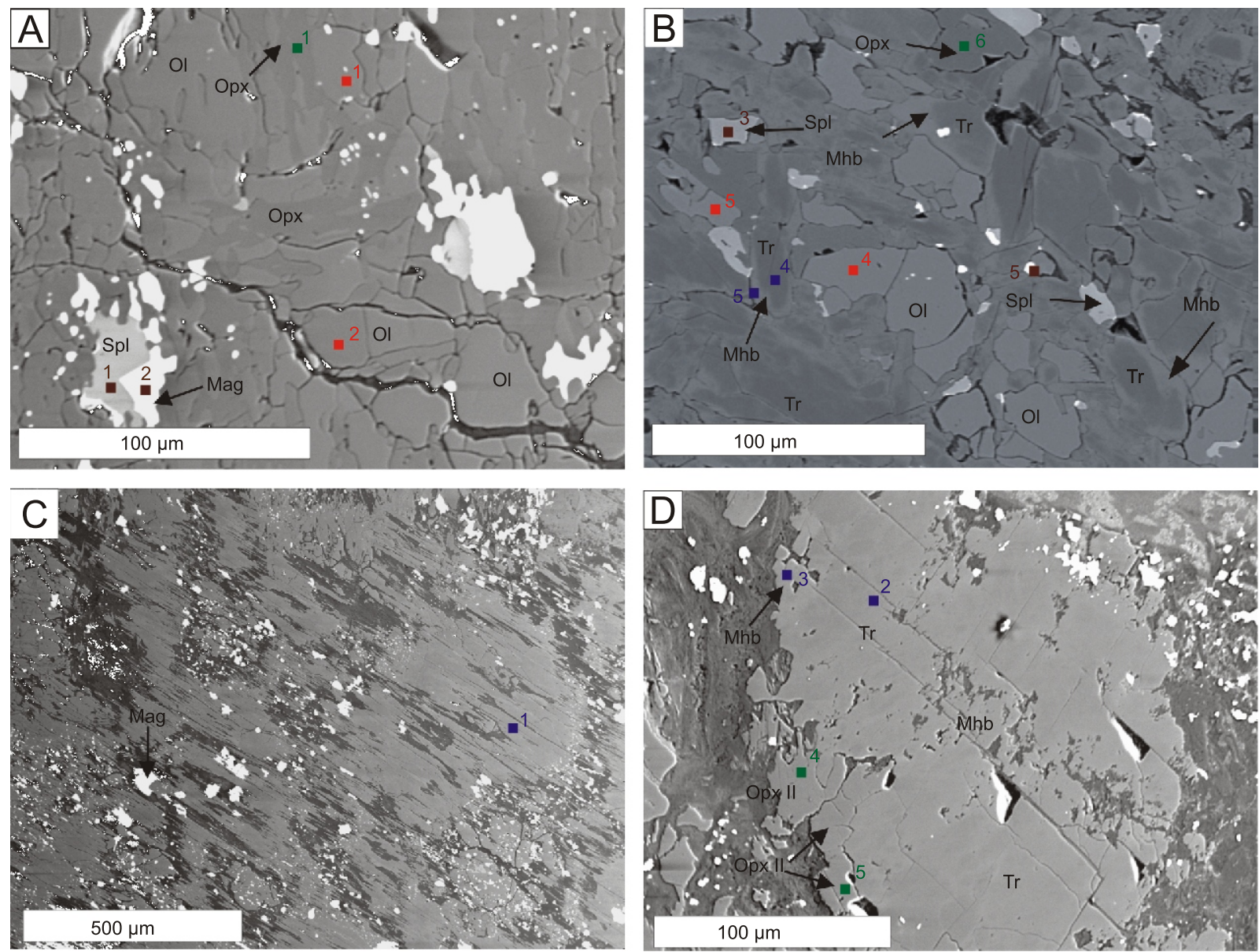

Fig. 3. Relationships among the minerals in the Popiel Hill peridotite

A - olivine-orthopyroxene aggregates with spinel and magnetite; $\mathbf{B}$ - relics of olivine and spinel, embedded in tremolitic amphibole with thin magnesiohornblende rims; $\mathbf{C}$ - aggregate of acicular amphibole; D - small grains of orthopyroxene II located at the margin of tremolite-magnesiohornblende grain; the coloured points correspond to analyses in Appendices 1-4 

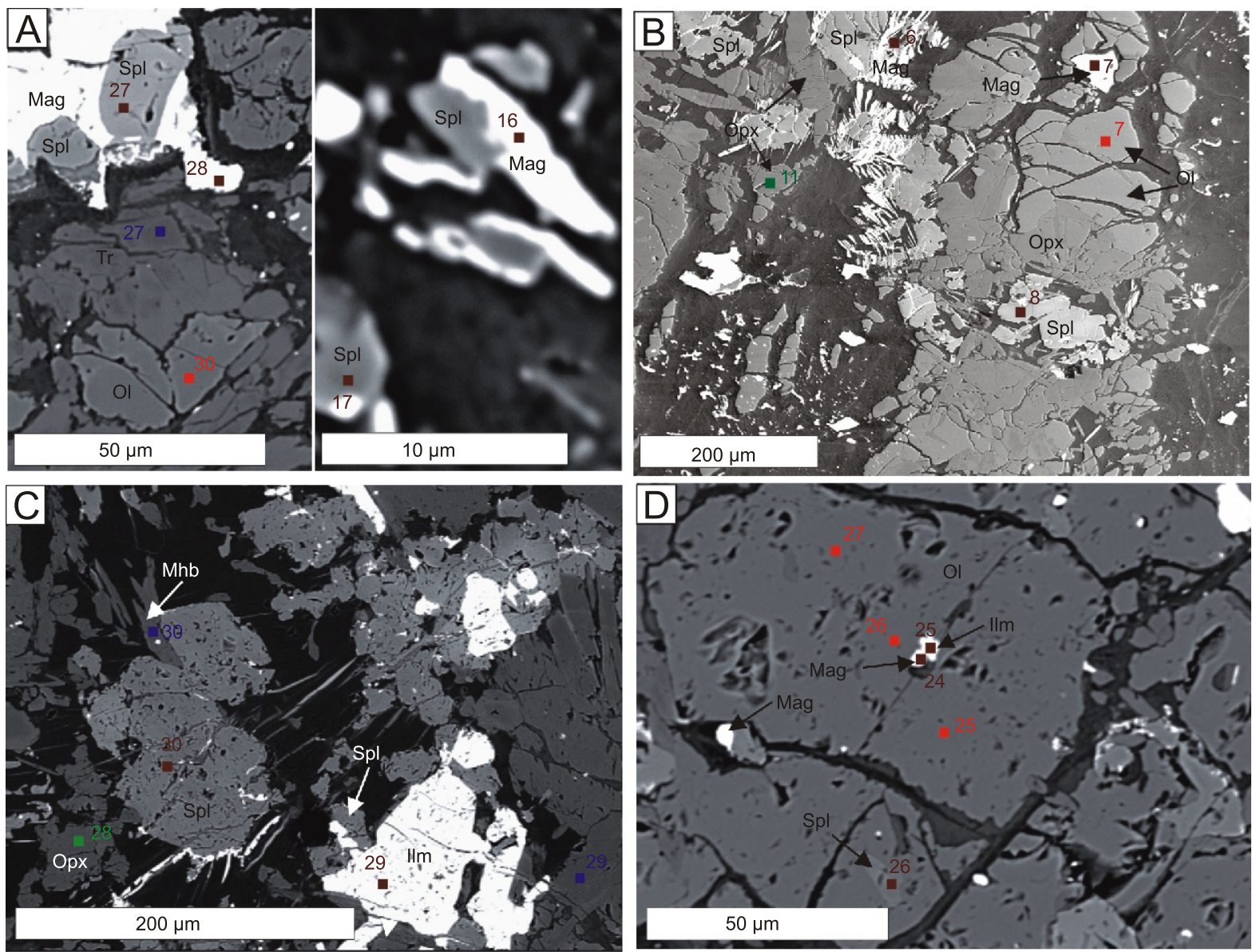

Fig. 4. Accessory phases in the Popiel Hill peridotite

A - magnetite rimming spinel in the amphibole-olivine aggregate; $\mathbf{B}$ - acicular magnetite on spinel; $\mathbf{C}$ - amaeboidal ilmenite coexisting with spinel and amphibole; D - small grains of ilmenite and magnetite, embedded in the olivine grain; other explanations as in Figure 3
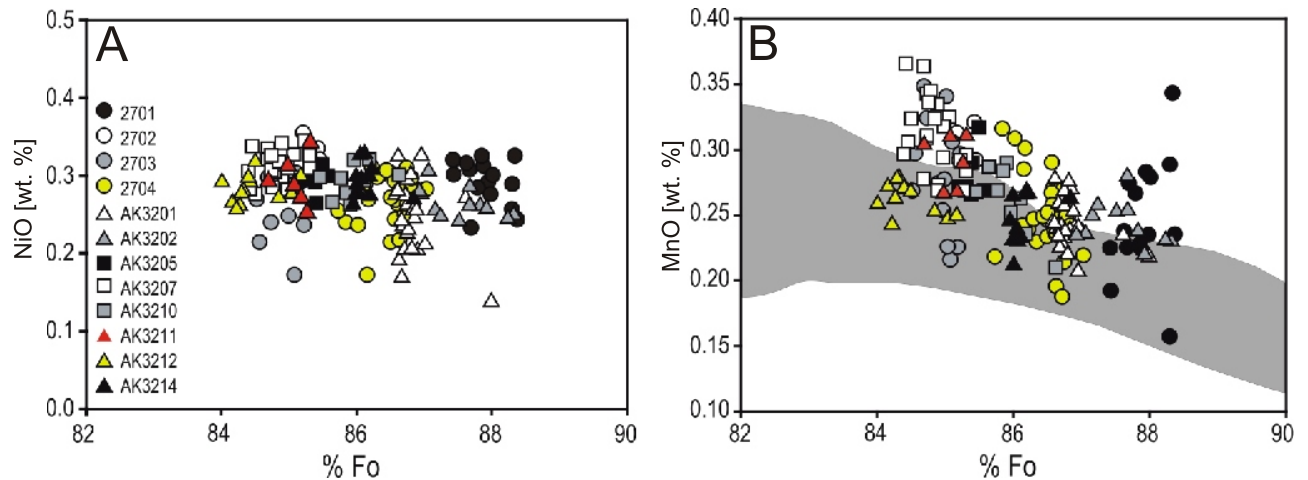

Fig. 5. Relationships between forsterite (Fo) and $\mathrm{NiO}(\mathrm{A})$ and $\mathrm{MnO}(\mathrm{B})$ content in olivine

The shaded field in (B) marks the range of olivine compositions from ultramafic rocks of the Chilas Complex in the Kohistan Palaeo-arc, Pakistan, interpreted to be tholeiitic magma cumulates

(Jagoutz et al., 2007) 


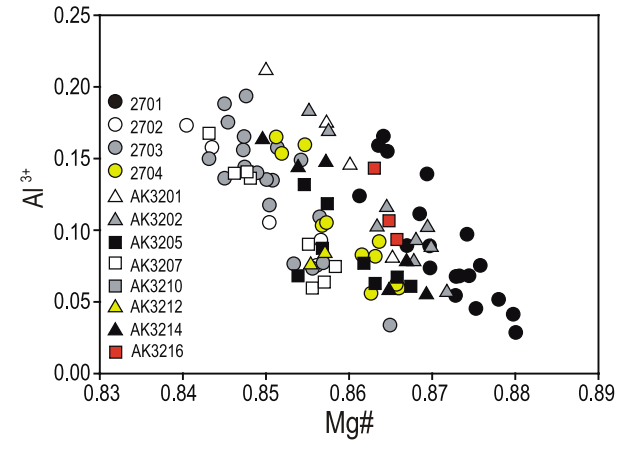

Fig. 6. Relationships between Mg\# and Al content in orthopyroxene
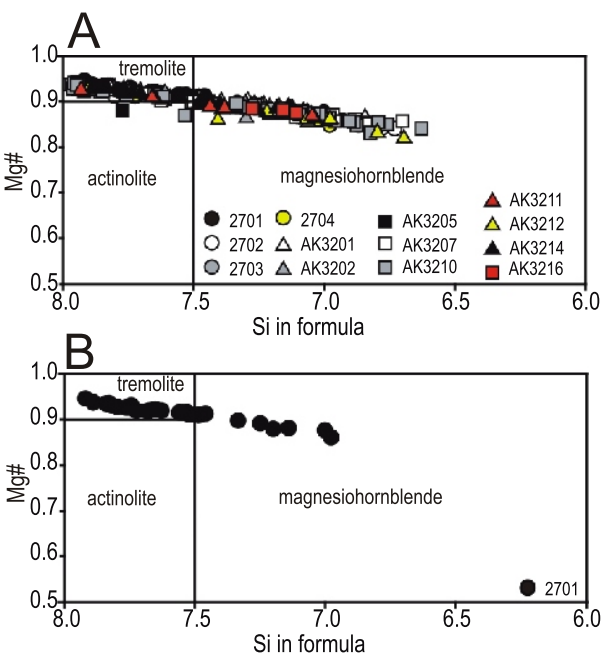

Fig. 7. The compositional variation of amphibole in the Popiel peridotite $(A)$ and in a single sample of the rock $(B)$ in the Mg\#-Si diagram of Leake et al. (1997)

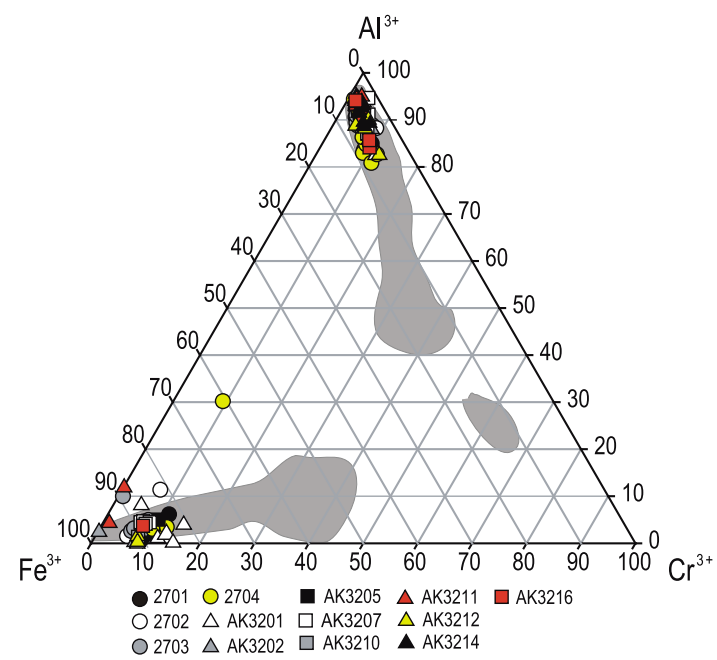

Fig. 8. Composition of spinels occurring in the Popiel peridotite in the $\mathrm{Fe}^{3+}-\mathrm{Al}-\mathrm{Cr}$ diagram. The shaded field marks the range of spinel compositions from ultramafic rocks of the Chilas Complex in the Kohistan Palaeo-arc, Pakistan, interpreted to be tholeiitic magma cumulates (Jagoutz et al., 2007)
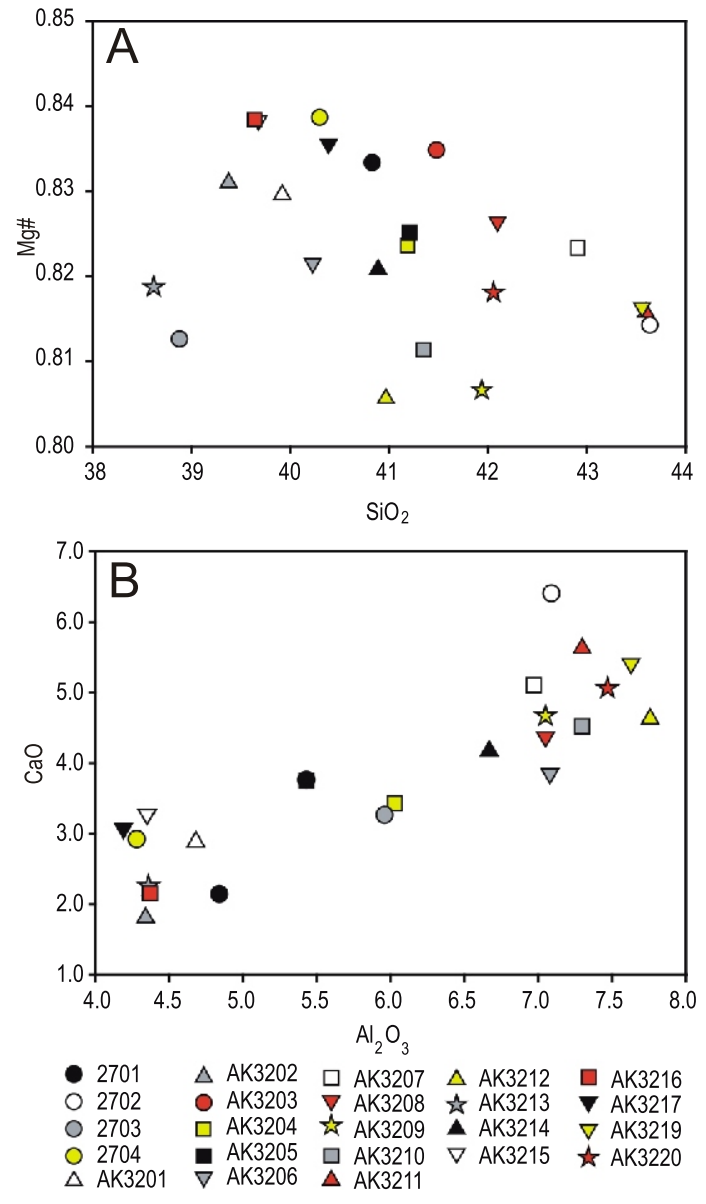

Fig. 9. Relationships between $\mathrm{SiO}_{2}$ content and $\mathrm{Mg \#}(\mathrm{A})$ and between $\mathrm{CaO}$ and $\mathrm{Al}_{2} \mathrm{O}_{3}$ contents $(\mathrm{B})$ in the Popiel peridotite

Magnetite is common; locally it occurs as aggregates of acicular grains up to a few tens of $\mu \mathrm{m}$ long (Fig. 4B). Ilmenite forms a few tens to ca. $100 \mu \mathrm{m}$ amaeboidal grains (Fig. 4C) or small $(<10 \mu \mathrm{m})$ inclusions in olivine (Fig. 4D). Iron sulfides (no quantitative analysis available) occur as scarce, amaeboidal interstitial grains up to $20 \mu \mathrm{m}$ across. Apatite forms scarce, elongated grains up to $50 \mu \mathrm{m}$ across.

The olivine composition in individual samples is relatively constant; the variation of forsterite content between samples is from 84.0 to 88.0 mole $\%$ of forsterite and from 0.14 to $0.36 \mathrm{wt} . \%$ $\mathrm{NiO}$ (Appendix 1*; Fig. 5). Orthopyroxene shows a significant variation in $\mathrm{Mg \#}(0.84-0.88)$ and $\mathrm{Al}$ content (0.03-0.20 apfu), which are negatively correlated (Fig. 6). The variation of chemical composition between samples is only slightly larger than that occurring on the scale of an individual sample (Appendix 2; Fig. 6). No relationship between the Al content/Mg\# and the location of the analysed spot occurs. Orthopyroxene II (cf. Fig. 3D) is the low Al/high Mg\# one (Appendix 2). The amphibole is highly magnesian (Mg\# from 0.82 to 0.92 ), and its chemical composition varies from tremolite to magnesiohornblende (Appendix 3; Fig. 7). The variation of mineral composition in an individual sample corresponds to that among the samples (Fig. 7). Chlorite is strongly magnesian and aluminium-rich: the formula calculated on the basis of 28 oxygens is $\left(\mathrm{Mg}_{8.92} \mathrm{Fe}_{0.68} \mathrm{Ni}_{0.02} \mathrm{Al}_{2.23}\right)_{11.85}\left(\mathrm{Si}_{5.84} \mathrm{Al}_{2.16}\right)_{8.00}$. Spinel is highly 

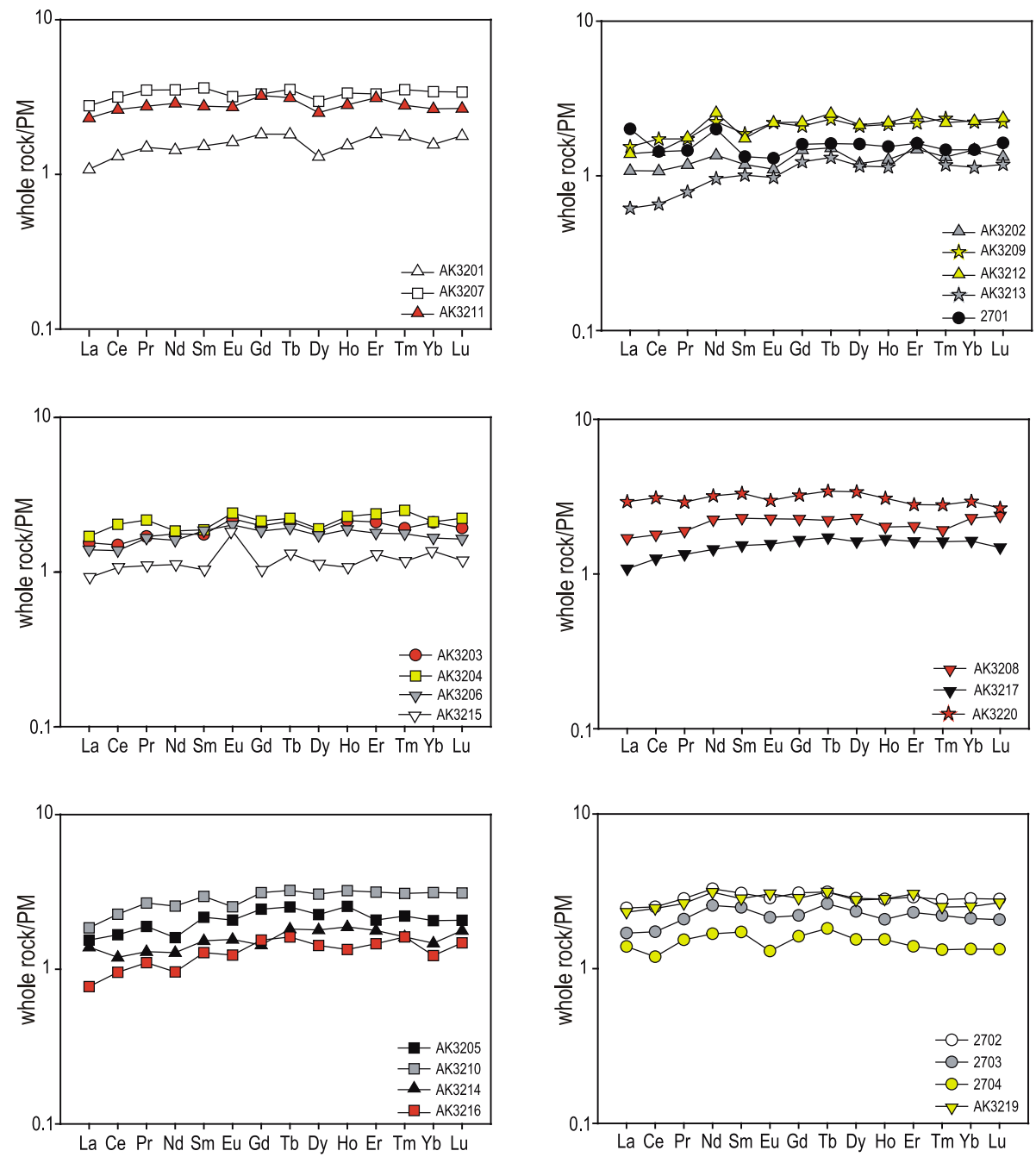

Fig. 10. Primitive mantle (McDonough and Sun 1995) normalized REE patterns of the Popiel peridotite

aluminous ( $\mathrm{Al}>1.70$ apfu; Appendix 4) and exhibits a slight variation in Al content (Fig. 8), whereas magnetite contains significant $\mathrm{Cr}$ (up to $0.21 \mathrm{apfu}$, Appendix 4; Fig. 8). Ilmenite, which is associated with magnetite and amphibole, contains significantly less $\mathrm{Mg}$ (ca. $2.5 \mathrm{wt}$ \% MgO) than the ilmenite in contact with olivine or that occurring as inclusions in olivine (ca. $6 \mathrm{wt} . \%$ $\mathrm{MgO}$; Appendix 4).

Bulk rock chemical analyses (Appendix 5) with $\mathrm{SiO}_{2}$ contents typically below 42 wt. $\%$ and high molar $\mathrm{Mg} /(\mathrm{Mg}+\mathrm{Fe})$ ratio 0.81-0.84 (Fig. 9A) suggest a peridotitic protolith. The $\mathrm{CaO}$ and $\mathrm{Al}_{2} \mathrm{O}_{3}$ are positively correlated (Fig. 9B).

The Popiel peridotite is slightly (up to 10 times) enriched in trace elements and rare earth elements (REE) relative to primitive mantle (Appendix 6; Figs. 10 and 11). Rare earth element diagrams normalized to primitive mantle are flat $\left(L a_{N} / Y b_{N}=\right.$ 0.54-1.36), some with a slight depletion in LREE (light REE). Positive or negative Eu anomalies occasionally occur, as well as the positive anomaly of $\mathrm{Nd}$ and the positive anomaly of Dy.

\section{DISCUSSION}

THE PROTOLITH

The relationships among the minerals forming the Popiel peridotite show that the rock primarily consisted of olivine, orthopyroxene, and spinel, plus a calcic ferromagnesian phase. The latter was completely replaced by tremolite, and can be only inferred from the significant amount of $\mathrm{Ca}$ in the rock. To determine if the calcic phase was hornblende or clinopyroxene, we calculated the $\mathrm{SiO}_{2}-\mathrm{CaO}$ relationships in the peridotite to which hornblende or clinopyroxene was added. The peridotite starting composition was assumed to be $\mathrm{SiO}_{2} 40.0, \mathrm{CaO}$ 2.0 wt.\% (corresponding to AK3202, Appendix 5). The hornblende was assumed to contain 50.0 wt.\% $\mathrm{SiO}_{2}$ and 12.0 wt. \% of $\mathrm{CaO}$ (corresponding to hornblendes in the Popiel peridotite), whereas clinopyroxene had $50.0 \mathrm{wt} . \% \mathrm{SiO}_{2}$ and 24.0 wt. \% CaO. The latter is a crude estimate based on the compositions of clinopyroxenes occurring in volcanic-arc cumulates containing no plagioclase or garnet, similar to those reported by e.g. Conrad and Kay (1983). The points representing the Popiel peridotite are located close to the line representing a varying amount of clinopyroxene (Fig. 12), suggesting that the mineral was the primary calcic phase occurring in the rock. Thus, the primary mineral assemblage seemingly consisted of olivine, ortho- and clino-pyroxene, and spinel.

The variation in major element bulk rock composition is mostly due to variations in $\mathrm{Ca}$ and $\mathrm{Al}$ contents, and is well-described by varying amounts of clinopyroxene in the rock. A precise discrimination between the harzburgite $(<5 \mathrm{vol} . \%$ of clinopyroxene) and Iherzolite ( $>5$ vol. \% of orthopyroxene, IUGS classification) is not possible using the bulk rock chemical composition because orthopyroxene always contains some $\mathrm{Ca}$ 

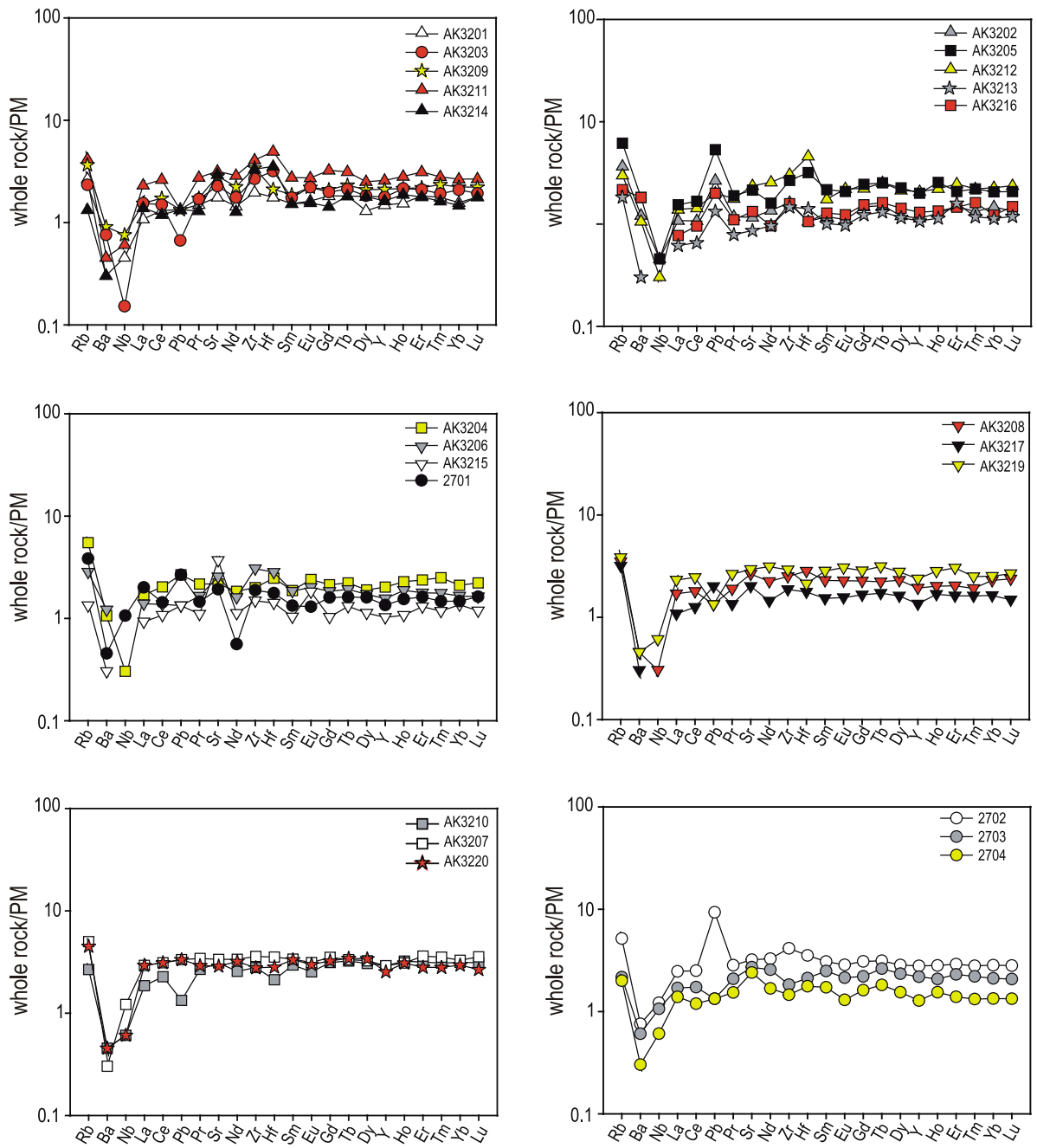

Fig. 11. Primitive mantle (McDonough and Sun, 1995) normalized trace element patterns of the Popiel peridotite

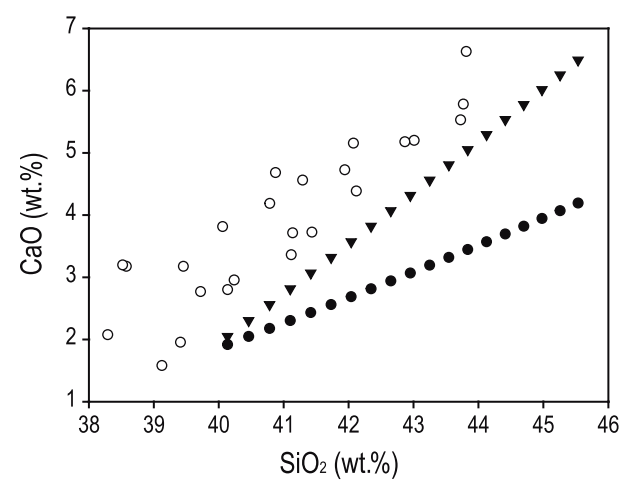

Fig. 12. Relationships between $\mathrm{SiO}_{2}$ and $\mathrm{CaO}$ content in the Popiel peridotite and the changes of the rock composition due to addition of hornblende and clinopyroxene

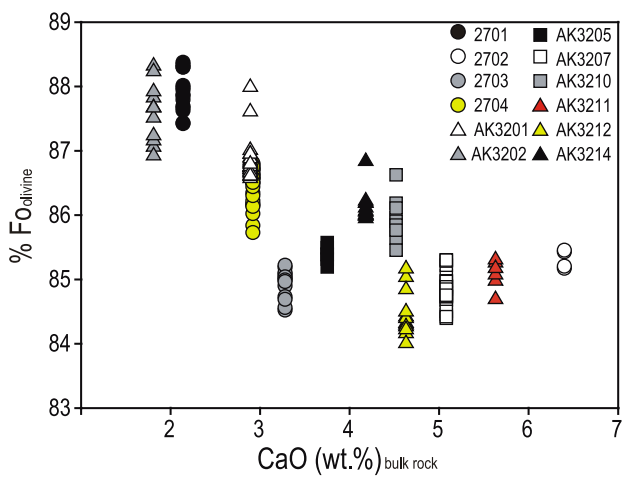

Fig. 13. Relationship between the bulk rock $\mathrm{CaO}$ content and forsterite content in olivine

See text for details 
and Al. However, even the orthopyroxene-rich spinel facies harzburgites contain $<0.8$ wt. $\%$ of $\mathrm{CaO}$ (see e.g., data of Perinelli et al., 2006). Since all the rocks analysed contain $>1.8 \mathrm{wt}$ \% $\mathrm{CaO}$, we assume that Iherzolite was their protolith.

The REE bulk rock patterns are slightly $(<10 \times)$ enriched relative to primitive mantle and flat, which suggests an island arc tholeiitic composition (e.g., Wilson, 1989). Those poorest in $\mathrm{CaO}$ (e.g., AK3213, AK3216, AK3202) are not enriched, and two of them (AK3213, AK3216) show a slight depletion in LREE. Those richest in $\mathrm{CaO}(>5.0$ wt. $\% \mathrm{CaO}$, AK3207, AK3211, AK3219, AK3220, 2702) show REE enrichment of ca. $5 \times$ relative to primitive mantle (Fig. 10). Similar conclusion can be drawn from trace element patterns. This relationship between REE contents and $\mathrm{CaO}$ contents in the rock suggests that clinopyroxene was the "missing" primary Ca-bearing phase, since that mineral concentrates REEs in the lherzolite mineral assemblages.

The strong grain fragmentation does not allow assessment of the primary rock texture. However, the remnants of primary olivine and orthopyroxene grains, as well as the ultramafic composition, point to a plutonic cumulate rock, and we follow the proposal of Gunia et al. (1998), that the rock is supposedly an ultramafic cumulate formed in an island arc root. The cumulates formed in volcanic arc roots show strongly variable compositions, both in terms of mineral and bulk-rock chemical composition, which is a function of the fractionating magma's starting composition, its water content, and oxygen fugacity, and of the pressure and temperature of crystallisation (see the data in e.g., Greene et al., 2006; Dhuime et al., 2009; Chen et al., 2009).

The relics of the primary phases contribute little to the understanding of the nature of the primary magmatic system. The composition of olivine is mostly a function of its crystallisation temperature. The $\mathrm{NiO}$ content of the mineral shows no correlation with forsterite content (Fig. 5A). The Popiel olivine is rich in $\mathrm{MnO}$ (Fig. 5B), such contents being partly similar to that of ultramafic rocks occurring in the roots of island arcs, e.g., in the Chilas Complex of the Kohistan Palaeo-arc (Jagoutz et al., 2007, cf. Fig. 5b). A crude correlation between the Fo content in olivine and the $\mathrm{CaO}$ content in the host rock occurs (Fig. 13). Since the $\mathrm{CaO}$ reflects the clinopyroxene volume in the primary mineral assemblage, we interpret this as a record of temperature decrease in a fractionating tholeiitic magma, leading to a decrease of Fo content in olivine and a concomitant increase in the proportion of crystallizing clinopyroxene. The good positive correlation of Al vs. Mg\# in orthopyroxene (Fig. 6), occurring in the Popiel peridotite, is not diagnostic for any kind of tectonic setting, although it occurs also in the ultramafic members of volcanic arc roots (e.g., DeBari and Coleman, 1986). The composition of spinel, which is characterized by very low $\mathrm{Cr} \#(<0.2)$ and high Mg\# (0.5-0.8), does not fit those typical of arc-root ultrabasic rocks (cf. DeBari and Coleman, 1986; Spandler et al., 2003), which are richer in Cr. The spinel is commonly intimately overgrown with magnetite (see Fig. 4), and we suggest that the mineral was affected by a secondary exchange of $\mathrm{Cr}$ with magnetite, which altered the primary composition.

\section{THE METAMORPHISM}

The primary mineral assemblage underwent metamorphism, which produced tremolite. The brittle deformation of the rock, together with the preservation of a significant part of the primary igneous mineral assemblage, suggests a relatively fast uplift, probably due to thrusting along the Intra-Sudetic Fault. We infer that also serpentine and magnetite originated at this stage of the Popiel peridotite's history. We assume that the rock was emplaced at relatively shallow depths corresponding to pressures of $0.2 \mathrm{GPa}$, or slightly lower. This corresponds to the pressure of contact metamorphism around the Karkonosze granite intrusion at the current level of exposure (the andalusite and cordierite assemblage is typical of the metapelites altered at the contact with the granite - Teissyere, 1973). The tremolite, serpentine, and olivine assemblage in the CMASH system is stable in the relatively narrow temperature range of $375-475^{\circ} \mathrm{C}$ under 0.2 GPa in the P-T diagram (Bucher and Frey, 1994 and references therein). Therefore, its occurrence in the Popiel peridotite shows that the temperature was in this range at the level of the final emplacement of the rock before granite intrusion. The final event affecting the Popiel peridotite was the growth of hornblende, which forms rims on tremolite. That was related to the close proximity of the Karkonosze intrusion. The contact effect was small, since the tremolite is only incipiently changed into hornblende, and the serpentine seems not to be affected. The small extent of contact metamorphism suggests that the neighbouring part of the Karkonosze granite was probably formed by small magma increments, which did not heat much of the surrounding rocks. It also places age limits on the tectonic emplacement of the Popiel peridotite, since the granite is dated at $312 \mathrm{Ma}$ (Kryza et al., 2014) and peridotite emplacement preceded the granite intrusion.

\section{CONCLUSIONS}

The peridotite from Popiel Hill in the Western Sudetes (SW Poland) is fine- to very-fine grained, which is a result of strong grain-size reduction during - supposedly rapid - uplift of the rock, probably on the Intra-Sudetic Fault, during the Variscan Orogeny. Bulk-rock chemical compositions show that its protolith was Iherzolite. Our rare earth- and trace-element data support the earlier ideas of Narębski $(1990,1993)$ that the rock originated in the supra-subduction region, and we follow the idea of Gunia et al. (1998) that it originated due to crystal settling. However, we suggest that the parental melt had the composition of an island arc tholeiite.

The uplift rate of the Popiel peridotite was fast enough to allow a large part of the primary mineral assemblage (olivine, orthopyroxene, and spinel) to be preserved, although retrogressive tremolite and serpentinite replaced part of the primary phases. The rock was exhumed to a pressure of $0.2 \mathrm{GPa}$ (corresponding to a depth of ca. $7 \mathrm{~km}$ ) and embedded into the low-grade metabasic rocks of the Rudawy Janowickie Complex. At this level, the peridotite was affected by contact metamorphism by the Karkonosze Granite intrusion. The contact metamorphism resulted in hornblende crystallisation, which, however, is volumetrically subordinate.

Acknowledgements. This study is based on the MSc thesis of the first author, realised at the Institute of Geological Sciences, University of Wrocław, Poland, in 2010-2012. We thank R. MacDonald and two anonymous reviewers for their constructive comments, which significantly helped to improve an earlier version of the manuscript. Financial support from Institute research funds (1017/S/ING) made possible the analytical part of the study. The microprobe analyses were done thanks to the 2010-2011 project in the framework of an Austrian-Polish scientific and cultural cooperation agreement (Institute of Geological Sciences, University of Wroclaw and Department of Lithospheric Sciences, University of Vienna). 


\section{REFERENCES}

Aleksandrowski, P., Kryza, R., Mazur, S., Żaba, J., 1997. Kinematic data on major Variscan strike-slip faults and shear zones in the Polish Sudetes, northeast Bohemian Massif. Geological Magazine, 134: 727-739.

Berg, G., 1912. Geologische Karte von Preußen und benachbarten Bundesstaaten. Blatt Kupferberg mit Erläuterungen. Preußische Geologische Landesanstalt.

Berg, G., 1938. Erläuterungen zu Blatt Kupferberg der Geologischen Karte von Preußen und benachbarten Deutschen Ländern. Preußische Geologische Landesanstalt.

Bucher, K., Frey M., 1994. Petrogenesis of Metamorphic Rocks. Springer-Verlag, Berlin-Heidelberg.

Chen, B., Suzuki, K., Tian, W., Jahn, B.M., Ireland, T., 2009. Geochemistry and Os-Nd-Sr isotopes of the Gaositai Alaskan-type ultramafic complex from the northern China craton: implications for mantle-crust interaction. Contributions to Mineralogy and Petrology, 158: 683-702.

Conrad, W.K., Kay, R.W., 1983. Ultramafic and mafic inclusions from Adak Island: crystallization history, and implications for the nature of primary magmas and crustal evolution in the Aleutian Arc. Journal of Petrology, 25: 88-125.

DeBari, S. M., Coleman, R. G., 1989. Examination of the deep levels of an island arc: Evidence from the Tonsina ultramafic-mafic assemblage, Tonsina, Alaska. Journal of the Geophysical Research, 94: 4373-4391.

Dhuime, B., Bosch, D., Garrido, C.J., Bodinier, J.-L., Bruguier, O., Hussain, S.S., Dawood, H., 2009. Geochemical architecture of the lower to midle crustal section of a paleo-island arc (Kohistan Complex, Jijal-Kamila area, northern Pakistan): implications for the evolution of an oceanic subduction zone. Journal of Petrology, 50: 53-569.

Greene, A. R., DeBari, S. M., Kelemen, P. B., Blusztajn, J., Clift, P. D., 2006. A detailed geochemical study of island arc crust: the Talkeetna arc section, South-Central Alaska. Journal of Petrology, 47: 1051-1093.

Gunia, P., Ziółkowska-Kozdrój, M., Kozdrój, W., 1998. New geochemistry data of ultrabasic rocks from eastern surroundings of the Karkonosze Granite Instrusion (Sudetes, SW Poland). Bulletin of the Polish Academy of Sciences, Earth Sciences, 46: 93-108.

Jagoutz, O., Müntener, O., Ulmer, P., Pettke, T., Burg, J.-P., Dawood, H., Hussain, S., 2007. Petrology and mineral chemistry of lower crustal intrusions: the Chilas Complex, Kohistan (NW Pakistan). Journal of Petrology, 48: 1895-1953.

Kretz, R., 1983. Symbols for rock-forming minerals. American Mineralogist, 68: 277-279.

Kryza, R., Mazur, S., Pin, C.,1995. Leszczyniec meta-igneous complex in the eastern part of the Karkonosze-Izera Block, Western Sudetes: trce element and Nd isotope study. Neuses Jahrbuch für Mineralogie Abhandlungen, 170: 59-74.

Kryza, R., Schaltegger, U., Oberc-Dziedzic, T., Pin, C., Ovtcharov, M., 2014. Geochronology of a composite granitoid pluton: a high-precision ID-TIMS U-Pb zircon study of the Variscan Karkonosze granite (SW Poland). International Journal of Earth Sciences, 103: 683-696.

Leake, B.E., Woolley, A.R., Arps, C.E.S., Birch, W.D., Gilbert, M.C., Grice, J.D., Hawthorne, F.C., Kato, A., Kisch, H.J., Krivovichev, V.G., Linthout, K., Laird, J., Mandarino, J.A., Maresch, W.V., Nickel, E.H., Rock, N.M.S., Schumacher, J.C., Smith, D.C., Stephenson, N.V.N., Ungaretti, L., Whittaker, E.J.W., Youzhi, G., 1997. Nomenclature of amphiboles. Report of the Subcommittee on Amphiboles of the International Mineralogical Association, Commission on New Minerals and Mineral Names. American Mineralogist, 82: 1019-1037.

McDonough, W.F., Sun, S.-S., 1995. The composition of the Earth. Chemical Geology, 120: 223-253.

Morimoto, N., 1989. Nomenclature of pyroxenes. Subcommittee on Pyroxenes, Commission on New Minerals and Mineral Names, International Mineralogical Association. Canadian Mineralogist, 27: 143-156.

Narębski, W., 1990. Petrotectonic affinities of Lower Silesian metabasites and the problem of origin of Paleozoic Sudetic ophiolites. In: International Conference on Paleozoic Orogens in Central Europe, Göttingen-Giessen, Abstract Book.

Narebski, W., 1993. Model of evolution of the north-eastern part of the Bohemian Massif - comment of a petrologist (in Polish with English summary). Przegląd Geologiczny, 41: 751-756.

Perinelli, C., Armienti, P., Dallai, L., 2006. Geochemical and O-isotope constraints on the evolution of lithospheric mantle in the Ross Sea rift area (Antarctica). Contributions to Mineralogy and Petrology, 151: 245-266.

Spandler, C.J., Arculus, R.J., Eggins, S.M., Mavrogenes, J.A., Price, R.C., Reay, A.J., 2003. Petrogenesis of the Greenhills Complex, Southland, New Zealand: magmatic differentiation and cumulate formation at the roots of a Permian island-arc volcano. Contributions to Mineralogy and Petrology, 144: 703-721.

Teisseyre, J., 1966. Perydotyt hornblendowy z Janowic Wielkich (Sudety Zachodnie). Archiwum Mineralogiczne, 26: 289-301.

Teisseyre, J., 1973. Metamorphic rocks of the Rudawy Janowickie and Lasocki Grzbiet ranges (in Polish with English summary). Geologia Sudetica, 8: 7-118.

Whitney, D.L., Evans, B.W., 2010. Abbreviations for names of rock-forming minerals. American Mineralogist, 95: 185-187.

Websky, M., 1853. Ueber die geognostischen Verhältnisse der Erzlagerstätten von Kupferberg und Rudelstadt in Schlesien. Zeitschrift der Deutschen Geologischen Gesellschaft, 5: 373-438.

Wilson, M., 1989. Igneous Petrogenesis. Springer, Dordrecht.

Winchester, J.A., Floyd, P. A., Chocyk, M., Horbowy, K., Kozdrój, W., 1995. Geochemistry and tectonic environment of Ordovician meta-igneous rocks in the Rudawy Janowickie Complex, SW Poland. Journal of the Geological Society, 152: 105-115. 